\title{
Role of living bacteria and other amendment in early development of maize
}

\author{
Klára Hubert \\ University of Debrecen Faculty of Applied Economics and Rural Development, Debrecen \\ hubert.klara@freemail.hu
}

SUMMARY

Different bacteria and wood ash, as a possible micro-nutrient, and liming material, was examined in our experiment on the early growth of corn seedlings.

The development of renewing energy resources includes the use of energy grasses and energy forests. The intensive land use in forestry and in agriculture may cause the acidification of soils due to the harvest, or leaching of cations. To maintain the sustainability of soils necessary to maintain it's the buffer capacity, and pH. Beside the lime the wood ash can is one of the most effective sources to provide the sustainability of intensive land use. The soil born micro organisms play a significant role in the maintenance of soil quality. The bio fertilizer, that contains soil originated bacteria (Azotobacter, and Bacillus sp.), was used in the experiments. The plants release several organic acids by their roots lowering the soil $\mathrm{pH}$, and make more available the sparingly soluble minerals. The amounts of released organic matter depend on stress intensity, as the high $\mathrm{pH}$ is. The soil life has a significant role to keep the soil conditions on sustainable level, since there are several similarities in nutrient uptake mechanism between the bacteria and higher plants. Advantageous effects of bio-fertilizer were observed in our experiments.

We came to the conclusion that the use of wood ash is recommended instead of lime for the improvement of acidic soils, on the evidence of its pH increasing effect. The wood ash contains several micronutrients in an optimum composition for forestry and agricultural plants. The solubility of heavy metals is very low; therefore there is no risk to use the wood ash in the agriculture and in the horticulture by our experiments. The retardation of growth at higher ash doses can be explained by the modification effect to the soil pH, as far as the original soil pH was $\mathrm{pH}$ 6.8 , and when ash was given to the soil, the $\mathrm{pH}$ increases to $7.8 \mathrm{pH}$, that is unfavourable for the uptake of most nutrients.

Keywords: wood ash, soil pH, bio-fertilizer

\section{ÖSSZEFOGLALÁS}

Kísérleteinkben különbözö anyagokat úgymint baktériumokat, fahamut, mint lehetséges mikro tápanyagokat, valamint meszesitö anyagokat vizsgáltunk a kukorica palánta korai fejlödésében.

A megújuló energiaforrások fejlődése magába foglalja az energiahordozó füvek és erdők felhasználását. A mezőgazdaság és erdőgazdálkodás kiterjedt fölhasználata a termötalaj elsavasodásához vezethet a betakarításnak és a kationok kilúgozódásának köszönhetöen. A fenntartható termötalaj megörzése érdekében, a talaj tárolókapacitását, illetve pH tulajdonságát fenn kell tartani. A mész mellett a fahamu az egyik leghatékonyabb anyag, ami biztositani tudja a kiterjedt földhasználat fenntarthatóságát. A termötalajban megszületö mikroorganizmusok fontos szerepet játszanak a talaj minöség megörzésében. A kísérletben olyan bio mütrágyákat használtunk, melyek talajból származó baktériumokat tartalmaznak (Azotobacter és Bacillus sp.). A növények szerves savakat termeltek és a gyökereiken keresztül csökkentették a talaj pH értékét, ezzel felhasználhatóvá téve a számukra fontos, lassan oldódó ásványi anyagokat. A szerves anyagok termelésének mennyisége az igénybevétel intenzitásától függ, mint ahogy a magas pH érték is. A termötalaj minöségének fenntartható szintje nagyban függ a termötalajtól, mivel számos hasonlóság van a tápanyag bevitel mechanizmusa, valamint a baktériumok és magasabb rendü növények között. Kísérleteinkben megfigyeltük a bio mütrágyák jótékony hatását.

Arra a következtetésre jutottunk, hogy a talaj savasságának javitására mész helyett a fahamu használata javasolt, a talaj pH-jára gyakorolt megnövekedett hatékonysága miatt. A fahamu optimális összetételben tartalmaz mikro tápanyagokat az erdögazdálkodás és mezögazdasági termelés számára. A nehézfémek oldódása meglehetösen alacsony, igy kísérletünk alapján a fahamu használatának nincs kockázata a mezögazdaságban illetve a kertészetben. A növekedés lassulása, nagyobb mennyiségü hamu használatakor azzal magyarázható, hogy hatása a talaj pH értékére megváltozott, mivel a talaj eredeti pH értéke 6,8 volt, a hamu hozzáadásával ez az érték 7,8-ra emelkedett, és ez kedvezötlen hatást gyakorolt a tápanyag felszivódási folyamatra.

Kulcsszavak: fa hamu, a talaj pH, bio-mütrágya

\section{INTRODUCTION}

The trees accumulate the minerals from the soils in several decades. By the lumber of forest large amounts of cations are removed from the field that leads to the decrease of buffer capacity. The soils become more acidic, the uptake of heavy metals increases, which may cause toxicity and eventually the destruction of forests. The energy-forests and energy grasses will play an important role, as renewing energy resources. The intensive land use, the irrigation in agriculture also can cause a significant decrease of cations. To provide the sustainable soil quality, maintain the buffer capacity of soils, it is necessary to feed back these minerals. The effect of wood ash was longer lasting in liming experiments and the production of crops was higher. The availability of phosphorous was better using wood ash instead of lime (Lickacz, 2002). Higher oil contents of oil rape seeds were observed in experiments, on former forest soil, where the $\mathrm{pH}$ was below 6.0, and wood ash was applied (Patterson et al., 2004). The main problem to use the wood ash in agriculture is its cadmium contents; although the cadmium is a natural component of our soils (Grant et al., 1998).

It is generally agreed that rhizosphere microorganisms can influence the aquisition of phosphorus, and iron 
via their effects on root morphology and physiology and via their physiological processes. The aim of this work was to investigate the effects of wood-ash and a living bacteria containing biofertilizer for the early development of corn plants.

\section{MATERIAL AND METHODS}

Corn (Zea mays L. cvs. Norma SC) seeds were used in the experiments. The seeds were germinated on moistened filter paper at $25^{\circ} \mathrm{C}$. The seedlings were then transferred to a continuously aerated nutrient solution of the following composition: 2,0 $\mathrm{mM} \mathrm{Ca}\left(\mathrm{NO}_{3}\right)_{2}, 0,7 \mathrm{mM}$ $\mathrm{K}_{2} \mathrm{SO}_{4}, 0,5 \mathrm{mM} \mathrm{MgSO}{ }_{4}, 0,1 \mathrm{mM} \mathrm{KH}{ }_{2} \mathrm{PO}_{4}, 0,1 \mathrm{mM}$ $\mathrm{KCl}, 1 \mu \mathrm{M} \mathrm{H}_{3} \mathrm{BO}_{3}, 1 \mu \mathrm{M} \mathrm{MnSO}_{4}, 0,25 \mu \mathrm{M} \mathrm{CuSO}_{4}$, $0,01 \mu \mathrm{M}\left(\mathrm{NH}_{4}\right)_{6} \mathrm{Mo}_{7} \mathrm{O}_{24}$. The iron was given to the nutrient solution as Fe-EDTA in a concentration of $10^{-4} \mathrm{M}$. The wood-ash was given to the nutrient solution as powder in an amount of $1 \mathrm{~g} \mathrm{~L}^{-1}$ and as a soluble part of
$1 \mathrm{~g}$ wood ash. The biofertilizer was added to nutrient solution in an amount of $1 \mathrm{ml} \mathrm{L}^{-1}$. The seedlings were grown under controlled environmental conditions (light/ dark regime $10 / 14 \mathrm{~h}$ at $24 / 20^{\circ} \mathrm{C}$, relative humidity $65-$ $70 \%$ and a photosynthetic photon flux of $390 \mathrm{mEm}^{-2} \mathrm{~s}^{-1}$ at plant height. The contents of elements were measured by ICP. The release of organic acid was examined by root-disc-method and the amounts of organic acids were measured by HPLC.

\section{RESULTS AND DISCUSSION}

It is proved that the wood ash originating heavy metals bound to the organic matter in the soil, and their availability dramatically decreases. The contents and the solubility of different elements in ash were measured under different $\mathrm{pH}$ values. The results are shown in Table 1.

The contents of different elements in washing solution and in wood ash

Table 1.

\begin{tabular}{|c|c|c|c|c|c|c|c|c|}
\hline \multicolumn{9}{|c|}{ Contents of some elements in wood ash $\left(\mathrm{mg} \mathrm{Kg}^{-1}\right)$} \\
\hline & $\mathrm{Ca}$ & $\mathrm{Cd}$ & $\mathrm{Cu}$ & $\mathrm{Fe}$ & $\mathrm{Mg}$ & $\mathrm{Mn}$ & $\mathrm{P}$ & $\mathrm{Al}$ \\
\hline & $343070 \pm 7725$ & $3.3 \pm 0.07$ & $97.7 \pm 2.9$ & $4235 \pm 217$ & $19378 \pm 527$ & $11870 \pm 411$ & $34042 \pm 4750$ & $4018 \pm 150$ \\
\hline \multicolumn{9}{|c|}{ Contents of some elements in buffer solution after 8 hours shaking $\left(\mathrm{mg} \mathrm{L}^{-1}\right)$} \\
\hline $\mathrm{pH} 5$ & $6.71 \pm 1.63$ & $<0.001$ & $0.085 \pm 0.001$ & $0.009 \pm 0.001$ & $0.34 \pm 0.03$ & $0.02 \pm 0.004$ & $86.96 \pm 18.5$ & $0.193 \pm 0.08$ \\
\hline pH 6 & $3.08 \pm 1.01$ & $<0.001$ & $0.035 \pm 0.004$ & $0.005 \pm 0.001$ & $0.22 \pm 0.01$ & $0.01 \pm 0.001$ & $178.3 \pm 37.0$ & $3.48 \pm 1.280$ \\
\hline $\mathrm{pH} 7$ & $1.39 \pm 0.04$ & $<0.001$ & $0.015 \pm 0.010$ & $0.004 \pm 0.001$ & $0.20 \pm 0.01$ & $0.01 \pm 0.001$ & $396.0 \pm 75.0$ & $6.80 \pm 1.650$ \\
\hline
\end{tabular}

As Table 1 shows, the contents of several elements are extremely high in the sample. The concentrations of micronutrients are in optimum amounts in the ash, so we can consider the ash can be a micronutrient-fertilizer. To feed back these micro-, and macro nutrients to the soils the acidification can be retarded. Beside the nutritional effect, because of its high calcium contents, we can substitute the lime with wood ash.

Each form of wood ash had a strong increasing effect on $\mathrm{pH}$. The composition of released organic acids is different, depending on plant species, and environmental stress. Table 2 shows the release of main organic acids by the roots of corn under $\mathrm{pH}$ stress. The release of citric acid and malic acid is very intensive, and increases in line with stress intensity. Therefore to use the wood ash in soils, where the $\mathrm{pH}$ is around 7 , the treatment can cause a significant decrease in dry matter production. The treatment with wood ash had an effect of root formation of corn seedling (Picture 1). The control (4) nutrient solution contained half amounts of nutrients, therefore deficiency symptoms can be seen, while the treated (6) nutrient solution was completed with wood ash of $1 \mathrm{~g} \mathrm{~L}^{-1}$. The root development of treated seedling was more intensive, the total amounts of root dry matter were almost doubled, and as a consequence, the growth of shoots also increased.

Serious effects on root morphology were observed when the nutrient solution was completed with wood ash with or without biofertilizer. The corn seedlings grown on nutrient solution containing half amounts of nutrients show nutrient-deficiency symptomes, these symptomes are reduced when the nutrient solution was completed with wood ash. The wood ash and the biofertilizer had a well seen co-effect. There are no deficiency symptomes observed, and the wood ash solution applied in a $10 \mathrm{ml} \mathrm{L}^{-1}$ concentration together with biofertilizer had an adventageous effect on shoot and root development (Pictures 1-2).

Release of different organic acids by the roots of corn under $\mathrm{pH}$ stress $\left(\mathrm{pH} 8-9-10, \mathbf{m g ~ L}^{-1}\right)$

\begin{tabular}{lccc}
\hline & $\mathrm{pH} 8$ & $\mathrm{pH} 9$ & $\mathrm{pH} 10$ \\
\hline Citric & $1.003 \pm 0.0150$ & $1.239 \pm 0.1010$ & $1.875 \pm 0.140$ \\
Malic & $0.804 \pm 0.0830$ & $0.937 \pm 0.0650$ & $0.979 \pm 0.120$ \\
Lactic & $0.099 \pm 0.0070$ & $0.055 \pm 0.0040$ & $0.060 \pm 0.007$ \\
Fumaric & $0.005 \pm 0.0009$ & $0.002 \pm 0.0005$ & $0.011 \pm 0.003$ \\
Trans-aconitic & $0.198 \pm 0.0110$ & $0.200 \pm 0.0200$ & $0.381 \pm 0.060$ \\
\hline
\end{tabular}


Picture 1: Maize seedlings grown on nutrient solution (4: $50 \%$ nutrients content in solution; 6 : the 4 . is completed with $1 \mathrm{ml} \mathrm{L}^{-1}$ wood ash solution)

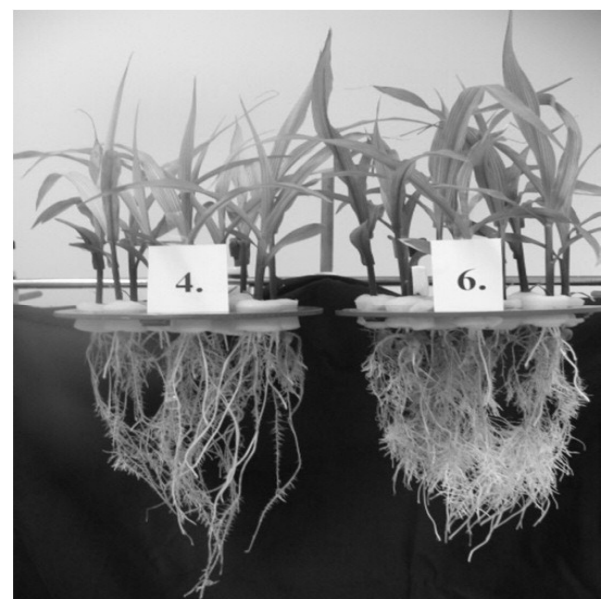

The effects depend on the concentrations of wood ash. The biofertilizer, because of its living bacteria content, can moderate the changes in $\mathrm{pH}$, but this effect is limited. It seems to be reasonable, that sufficient soil life is needed to use the wood ash in agriculture. The effect of wood ash on the $\mathrm{pH}$, and the moderation effect of biofertilizer can be seen on Table 3 .

The moderation effect of biofertilizer on $\mathrm{pH}$ is well seen.

The effects of applied treatments on dry matter accumulation can be seen on the following Table 4 .
Picture 2: Maize seedling grown on nutrient solution completed with $1 \mathrm{ml} \mathrm{L}^{-1}$ biofertilizer and wood ash solution (10: $1 \mathrm{ml} \mathrm{L}^{-1}$; 12: $10 \mathrm{ml} \mathrm{L}^{-1}$; 14: $100 \mathrm{ml} \mathrm{L}^{-1}$ )

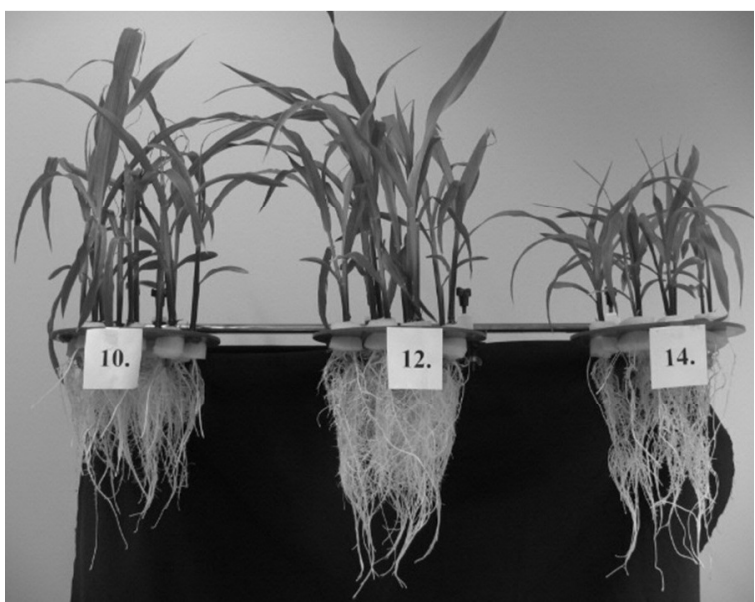

The treatments started when the seedlings were one week old.

The decrease of dry matter accumulation is strongly retarded by the applicaton of wood ash. The biofertilizer could moderate.

The decrease of dry matter accumulation on lower level in comparison to the control.

We suppose, that this retardation in dry matter accumulation is in tigh connection with the increasing $\mathrm{pH}$.

Table 3 .

Effects of wood ash and biofertilizer on $\mathrm{pH}$ of nutrient solution of corn seedlings

\begin{tabular}{lrrrc}
\hline \multicolumn{1}{c}{ Treatments } & \multicolumn{1}{c}{ 0. day } & 2. day & 4. day & 6. day \\
\hline Control & $6.81 \pm 0.59$ & $6.72 \pm 0.41$ & $6.49 \pm 0.38$ & $7.05 \pm 0.13$ \\
Biofertilzer $1 \mathrm{ml} \mathrm{L}^{-1}$ & $7.64 \pm 2.50$ & $6.92 \pm 0.21$ & $6.88 \pm 0.04$ & $7.16 \pm 0.37$ \\
$1 \mathrm{~g} \mathrm{~L}^{-1}$ wood ash & $10.82 \pm 0.61$ & $9.91 \pm 0.40$ & $9.09 \pm 0.63$ & $9.09 \pm 0.28$ \\
$1 \mathrm{~g} \mathrm{~L}^{-1}$ w. ash+Biof. $1 \mathrm{ml} \mathrm{L}^{-1}$ & $10.76 \pm 0.64$ & $9.73 \pm 0.18$ & $8.72 \pm 0.33$ & $7.87 \pm 0.32$ \\
\hline
\end{tabular}

Table 4

Dry matter accumulation of shoots and roots of maize and cucumber seedlings on the 4. day of treatments (gdm.plant $\left.{ }^{-1}\right)$

\begin{tabular}{|c|c|c|}
\hline Treatments & Shoot maize & Root maize \\
\hline Control & $4.0277 \pm 0.387$ & $1.2663 \pm 0.098$ \\
\hline Biofertilzer $1 \mathrm{ml} \mathrm{L}^{-1}$ & $4.5947 \pm 0.279$ & $1.1932 \pm 0.067$ \\
\hline $1 \mathrm{~g} \mathrm{~L}^{-1}$ wood ash & $2.6168 \pm 0.410$ & $1.2270 \pm 0.102$ \\
\hline $1 \mathrm{~g} \mathrm{~L}^{-1} \mathrm{w}$. ash + Biof. $1 \mathrm{ml} \mathrm{L}^{-1}$ & $3.0174 \pm 0.312$ & $1.2412 \pm 0.091$ \\
\hline
\end{tabular}

\section{CONCLUSIONS}

The use of wood ash is recommended instead of lime for the improvement of acidic soils, on the evidence of its $\mathrm{pH}$ increasing effect. The wood ash contains several micronutrients in an optimum composition for forestry and agricultural plants. The solubility of heavy metals is very low; therefore there is no risk to use the wood ash in the agriculture and in the horticulture by our experiments. The effects of wood ash were different on the monocot corn, and the dicot plants. The monocot corn seems to be more sensitive. This effect is contradictory, since the uptake of some important micronutrient based on siderophore release by the roots of monocots, and therefore these plants are less sensitive to the soil $\mathrm{pH}$. The retardation of growth at higher ash doses can be explained by the modification effect to the soil $\mathrm{pH}$, as far as the original soil $\mathrm{pH}$ was $\mathrm{pH} 6.8$, and when ash was given to the soil, the $\mathrm{pH}$ increases to $7.8 \mathrm{pH}$, that is unfavourable for the uptake of most nutrients. 


\section{REFERENCES}

Grant, C. A.-Buckey, W. T.-Bailey, L. D.-Selles, F. (1998): Cadmium accumulation in crops. Can. J. Plant Sci. 73: 1-17.

Lickacz, J. (2002): Wood Ash- an Agricultural Liming material for Agricultural Soils. Agri-facts. Febr. 2002. Alberta. Canada.
Patterson, S. J.-Acharaja, S. N.-Bertschi, A. B.-Thomas, J. E. (2004): Application of Wood Ash to Acidic Boral Soils and its Effect on Oilseed Quality of Canola. Agr. J. 96: 1344-1348. 